\title{
INTERNATIONALIZATION OF CONSUMER LAW AND CONSUMER PROTECTION
}

Pozhodzhuk R.,

https://doi.org/10.32849/2409-9201.2018.18.46

Ph. D., Researcher of F. H. Burchak Scientific-Research Institute of Private Law and Entrepreneurship NALS of Ukraine

The article is devoted to issues of internationalization of consumer law and consumer protection. Also, the new trends in the field of consumer relations are considered. Special attention is paid to modern approaches of understanding the protection of consumer rights in the international context.

Keywords: internationalization, consumer law, protection of consumer rights, consumer relations, consumer interests.

Our world changes and consumer society changes, too. During last thirty years, we have been observed how world market liberalization and technological development affect on consumers relationships. Nowadays, consumer has more possibilities to get complex information about different goods, works and services from various sources. The development of Internet and social networks canceled borders between people and companies. Moreover, that development led to emerge the new era of communication and facilitation to access to the world markets for consumers from all over the world.

In an era of transnationalization, consumers are also facing more challenges. Due to the diversity of selling methods and new technology, the changing way of business practices, and the phenomenon of mass tourism, consumers are being exposed to new risks and fraudulent, deceptive, and unfair practices. Products and services (financial products in particular) are becoming progressively sophisticated and are difficult to assess even for experts. Subprime lending to lower-income consumers is considered the root cause of recent global financial crisis. In many occasions, consumers are provided with misleading information and advertisement. The disputes arising from cross-border consumption often turn out to be burdensome with low efficiency for consumers [1, p. 3-4]. We fully agree with author who pays attention to the diversity of selling methods and new technology, the changing way of business practices, and the phenomenon of mass tourism and comes to the logical conclusion that the above challenges can lead to new risks and fraudulent, deceptive, and unfair practices. In this context, it must be taken into account that the consumer as the weaker side of contractual relations must adapt to new methods, technologies, etc. and use them for the possibility of satisfying of his own interests.

Taking into consideration the fact that companies are constantly looking for and improving new methods of influencing on consumer in order to realize their own products, such consumer is an insecure side in consumer relations, and needs the additional protection.

The author also focuses on the low efficiency of consumer protection connecting with cross-border consumption. In accordance with this kind of protection, it should be noted that with the development of Internet commerce and with the possibility to purchase goods from the different parts of the world without leaving home, the consumer needs some kind of protection not only at the national level, but also at the international level. Due to this a consumer, who buys goods through Internet in another country, is deprived of the possibility of protection at the national level. In addition, the consumer cannot always effectively protect his rights through a specialized consumer protection authority in the country of purchase of goods. The reasons of low level of protection or its absence can vary, for example, the ignorance of the legislation of foreign country, the lack of access to specialized consumer protection authority in a foreign country, high expenses for a lawyer in comparison with the harm was done, etc. However, the consumer should be protected, both at the national and international levels. Such protection is possible in case of appealing to international consumer protection organizations.

At the same time, it should be noted that despite the existence of a significant number of international consumer protection organizations and international legal acts in the field of consumer protection, it is hard to claim that the consumer has an appropriate level of protection of his rights as a participant of consumer relations.

In the aspect of internationalization of consumer protection, the main attention should be paid to consumer interests. Usually, consumer interests can be defined as a legitimate desire to use certain tangible or intangible benefits. Therefore, it can be asserted that consumer interests are the main objective of any seller who is focused on the sale of goods, works and services directly to the consumer. Thus, the correct understanding of consumer interests is a key in a researching of a question of internationalization of consumer protection.

Although consumer issues consist of a wide range of topics, consumer interests can be clustered into three levels: fundamental, economic and societal interests:

- fundamental interests relate to the opportunity to participate in consumption. The subject of fundamental interests centres on the access to consumption and fair and equitable distribution of those goods that are essential for survival, e.g. water, food, or medicine. Fundamental consumer interests also include health, i.e. the interest that the consumer's health is not damaged or endangered by the products and services he or she consumes. 
- economic interests are often referred to as «classic» consumer interests. While fundamental interests focus on the access to the market, economic interests relate to consumer protection within the market. The foremost interest in this respect is the maximisation of benefit on the consumer's side with regard to the goods and services purchased. This also includes the best possible product quality at the lowest price.

- societal interests relate to the interest consumers have in their wider ecological and social environment. While it is undoubted that consumers want to live in an intact ecological and social environment, it is not as clear that they will make their purchasing decisions in such a way as to promote environmental protection, poverty eradication or labour rights. For a majority of consumers a gap still remains between everyday life in which economic considerations are still to a large extent predominant, and the degree of awareness for the support of societal interests. The consumer who decides to buy ecologically or socially beneficial goods or services will also benefit the public welfare or society as a whole, but in many cases the direct economic profit for the consumer himself remains immeasurable. Conversely, the consumer who buys ecologically or socially harmful goods, such as those produced by child labour, is unlikely to feel the societal consequences of this purchasing decision [2].

Today, we can talk about the internationalization of consumer protection in the aspect of each of three levels of consumer interests. All above said is caused by the globalization of almost all spheres of human life activity. Globalization is undoubtedly an integral part of modern society, manifested in the emergence of political, economic, social, ethical and legal interests beyond the boundaries of a particular state. As a result, specific interests are the subject of legal regulation of two or more states and, consequently, they require compliance with common principles of legal regulation.

Originally, consumer protection has been envisaged at a national level. Today, economic globalization increases the need to have universal standards to protect consumers both nationally and internationally and consumer law requires incorporating the international dimension. As an autonomous discipline, consumer law is distinct from traditional legal branches like civil law and commercial law by giving priority to the consumer rather than the transaction itself. Just as Thierry Bourgoignie has put it, consumer law offers a subjective understanding (instead of an objective conception) of the phenomenon of consumption as consumption is not a neutral process of technical destruction and the consumer plays a vital role on the market [3, p. 297; 1, p. 4]. The specificity of consumer law stands the recognition of the principle of vulnerability of the consumer in terms of information, choice, and negotiation capacity. In cross-border consumption relationships, the vulnerability of the consumer still remains and in most cases turns out to be much more obvious than the one reflected in internal transactions. Claudia Lima Marques pointed out some peculiar characteristics of international consumer transactions, namely, international consumer contracts are not longlasting and repetitive, the cost for upholding rights are much higher, the consumer, in addition to language barriers, is not familiar with foreign laws and jurisdictions and has more difficulty in having access to justice $[4$, p. 37-40; 1, p. 4].

In the global context, consumer law has to develop to «a truly international discipline» [5, p. 206; 1, p. 4]. The international community needs to develop common principles as well as concrete instruments to implement the goals or objectives of "consumer protection" listed in international treaties or legal documents. Taking into account the internationalization of consumer transactions, the international dimension of consumer law has to contain a number of themes [1, p. 4]. Hence, taking into full consideration the fact of globalization of consumer economy, protection of consumer has to be the core of consumer law. In this case, consumer needs to be protected not only by the national law, but also by international law. For this reason, international society has to create the unique principles of international consumer protection.

Some authors highlight the fact that there are two principal reasons for the increasing internationalization of consumer law. The first is that the experience of different national regulatory approaches towards consumer protection typically represents a form of material non-tariff obstacle for international trade [6]. Major global traders in the market advocate a unified consumer policy that facilitates their business activities. The alignment of diverse regulatory regimes of consumer protection amongst different countries encourages the development of cross-border trade and, in such a manner, increases commercial activities.

In this sense, the internationalization of consumer law corresponds with the phenomenon of globalization in all spheres of society, commercial transactions and the market. A particular challenge is the manner of protection of consumers on a global level. Trade liberalization, as a necessary prerequisite for globalization, and the development of unified systems of consumer protection can be seen as complementary rather than conflicting goals. The question remains, however, as to what the level should be of such consumer protection globally.

The second reason for the internationalization of consumer law is that many underdeveloped and developing countries either do not have consumer law regimes at all, or do not have adequately developed regimes. International organizations support the establishment and improvement of consumer law in these countries by providing models of consumer laws, and through offering diverse programmes and different types of support for the implementation of these models. 
This phenomenon is increasingly prevalent outside the developing countries due to the global financial crisis. The lack of an adequate system of consumer protection contributed to the occurrence of the crisis. Furthermore, it has also led to consumers, in particular vulnerable consumers, suffering from the consequence of the crisis in an unjustified and appropriate manner. Importantly, the defects of the regulatory regimes of consumer protection have been observed not only in developing countries, but also in a number of developed countries. It is for this reason that even the OECD ${ }^{1}$ has started to involve itself in the consumer policy of its Member States [7, p. 2]. The above, once again, confirms the urgent need for an appropriate internationalization of consumer law and protection of consumer rights. For this, first of all, it is necessary to accept as a dogma the fact that the consumer interests should be put on the first place not only at the national but also at the international level. At the same time, the international community needs to adopt a single international legal document (convention) on the protection of consumer rights. Such a convention should unite the countries in a common vision of the basic principles of consumer protection and liability for their violation.

Speaking about the internationalization of consumer law and consumer protection, we need to mention the paper, prepared by Policy Department A at the request of the Committee for Internal Market and Consumer Protection of European Parliament, which presents the emerging trends having an impact on consumers and identifies the challenges associated to them in the area of consumer protection. In this paper, Carine Piaguet classified the main new consumer trends and possible challenges connected with them in two groups. The first group named «New digital consumer trends and challenges» consists of the following components:

1) emergence of new digital products and services;

2) widespread use of internet as information tool for purchasing purposes;

3) increased use of electronic payments and emergence of new forms of payment;

4) traditional exchanges redefined through technology and peer communities: the development of sharing economy services.

The second group named «Non-digital consumer trends: the need for better information and knowledge» consists of following components.

1. Increased complexity of financial products and services.

2. Purchasing decisions increasingly influenced by environmental, social, ethical and other quality aspects.

3. A new environment leading to a new kind of vulnerable consumers [8]. In this context, it should be noted that the above research, classification and detailed analysis of the new trends testify the interest and awareness of some committees of the European Parliament on the current state of consumer relations. Therefore, it is logical to conclude that the specified interest and awareness clearly emphasize the importance of consumer protection and development of consumerism at the European Union level.

Undeniably, the given trends reflect the current state of consumer relations. However, the first group reflects the preconditions that are intended to facilitate the consumer's rights realization. Meanwhile, the second group reflects the real threats that require the immediate response.

Anyway, for appropriate legal regulation and consumer protection, the international community must not only reveal new consumer trends and possible challenges connected with them, but also to react on them. Appropriate reaction usually is reflected as the adoption of new international legal acts of various nature in the field of consumer rights protection, carrying out informational and educational work and activities for providing consumers the information that they can use to protect their rights and to prevent the violation of such rights.

\section{SUMMARY}

Summarizing the foregoing we can admit that the process of internationalization of consumer law and protection of consumer rights is inevitable. In my opinion, this process is due to four main factors: the globalization of consumption, the digitalization of consumption and consumer relations, the development of the Internet and social networks, and the impact of consumption on the environment. In this context, it is important to note that internationalization as a phenomenon should influence positively on the development of consumer relations and significantly expand the possibilities of the consumer. Consequently, the sphere of consumption should be reasonably regulated in accordance with challenges of the time and with the main goal - the protection of consumer rights.

\section{REFERENCES:}

1. Marques C. L., Wei D. (ed.). Consumer Law and Socioeconomic Development: National and International Dimensions. Springer, 2017. 492 p.

\footnotetext{
${ }^{1}$ The Organisation for Economic Co-operation and Development (OECD).
} 
2. Consumer Interests and Sustainable Development in International Trade Law, Federation of German Consumer Organizations (vzbv), Policy Brief https://www.ecologic.eu/sites/files/download/projekte/18501899/1885/1885 vzbv policy brief.pdf (Date of reference: 01.12.2017).

3. Bourgoignie T. Characteristics of consumer law // Journal of Consumer Policy. 1992. Vol. 14. Issue. 3. pp. 293-315.

4. Lima Marques C. (2012) Relations between international law and consumer law in the globalized world: challenges and prospects. In: Lima Marques C., Arroyo DPF, Ramsay I. et al. The Global Financial Crisis and the Need for Consumer Regulation: New Developments on International Protection of Consumers. 2012.

5. Twigg-Flesner C., Micklitz H. Think Global - Towards International Consumer Law // Journal of consumer policy. 2010. Vol. 33. Issue. 3. pp. 201-207.

6. Grainger, Andrew (2011) Trade facilitation: a conceptual review. Journal of World Trade, 45 (1). pp. 39-62. URL: http://eprints.nottingham.ac.uk/ 1769/1/TRAD_45\%281\%29_Andrew_Grainger.pdf (Date of reference: 01.12.2017).

7. Durovic M., Micklitz H. W. Internationalization of Consumer Law: A Game Changer. - Springer, 2016. URL: https://books.google.com.ua/books?id=g VV7DQAAQBAJ\&printsec=frontcover\&dq=Internationalization+ of + Consumer+Law: $+\mathrm{A}+$ Game + Changer\&hl=ru\&sa=X\&ved=0ahUKEwj565XruofYAhUjDZoKHYQeDmIQ6 AEIJjAA\# $\mathrm{v}=$ onepage $\& \mathrm{q}=$ Internationalization $\% 20 \mathrm{of} \% 20$ Consumer $\% 20 \mathrm{Law} \% 3 \mathrm{~A} \% 20 \mathrm{~A} \% 20 \mathrm{Game} \% 20 \mathrm{Change}$ $\mathrm{r} \& \mathrm{f}=$ false (Date of reference: 07.12.2017).

8. Carine Piaguet. New Trends and Key Challenges in the Area of Consumer Protection: In-depth Analysis. European Parliament. Directorate-General for Internal Policies of the Union. 2014. URL: http://www.europarl.europa.eu/RegData/etudes/IDAN/2014/518773/IPOL_IDA\%282014\%29518773_EN.pd $\mathrm{f}$ (Date of reference: 13.12.2017).

Пожоджук Р. В. Інтернаціоналізація споживчого права та захисту прав споживачів

Статтю присвячено питанням інтерначіоналізації спожсивчого права та захисту прав спожсвачів. Розглянуто нові тренди у сфері споживчих відносин. Особливу увагу приділено сучасним підходам до розуміння захисту прав споживачів у міжнародному контексті.

Ключові слова: інтернаціоналізація, споживче право, захист прав споживачів, споживчі відносини, інтереси споживача. 